2）櫻井欽一，小出五郎，松山外治郎：我等の磺物 92 (1940)

3）日本鈗物誌 (2版) 242 第 2 図

\title{
5. 三重縣水澤産煙水晶
}

Smoky Quartz from Suizawa, Mie Prefecture.

桜 井 欽 一* (Kin-ichi Sakurai)

三重県水沢のペグマタイト晶洞よりトパズ, カリ長石,曹長石, チンワルド 雲母等に伴つて産する煙水晶は一般に㖶灰色半透明で光沢はあまり著しくな い。太ん六角柱状の結晶で多くは晶洞内壁を被ら曹長石の連晶群中より晶洞 の中心に向つて笖出して未り, 大なるものでは径 $5.5 \mathrm{~cm}$, 長さ $8 \mathrm{~cm}$ に及ん でんる。接触測角器により炏の諸面が認められた。

$$
\begin{array}{lll}
m(10 \overline{1} 0), & r(10 \overline{1} 1), & z(01 \overline{1} 1), \\
M(30 \overline{3} 1), & \zeta(60 \overline{1} 1), & M_{1}(03 \overline{3} 1), \\
\zeta_{1}(06 \overline{6} 1), & s(11 \overline{2} 1), & x(51 \overline{6} 1), .
\end{array}
$$

$m, r, z$ は常に大きく発達しているが他の面は小さく, かつ現出も著しく 存ん。単晶叔よびドフィネー式双晶が見出される。本地の洷水晶中にはしばし ばトパズを抱んているものがあるが，それは包有関係でなく，トパズは必ず結 晶の一半を外部に現わしている。しばしば両端に晶面を有するここがあり， まを時には一つの大きな結晶の先端が多くの小結晶の本行連晶的族立に終つ てんることがある。

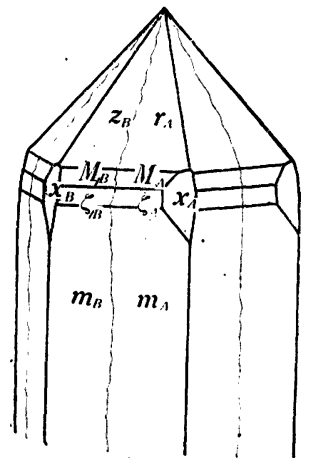

* 横浜大学学芸部 